\title{
Expression of Preproendothelin-2 Splice Variant in Cat
}

\author{
Tsuyoshi UCHIDE ${ }^{1)}$, Yuki FUJIMORI'), Kyosuke TEMMA ${ }^{1)}$, Takushi SASAKI ${ }^{1)}$, Aya MATSUU ${ }^{2}$, \\ Ushio FUKUSHIMA ${ }^{3)}$, Hiroshi ITOH $^{3)}$ and Kaname SAIDA ${ }^{4)}$
}

${ }^{1)}$ Laboratories of Toxicology, ${ }^{2)}$ Veterinary Internal Medicine I and ${ }^{3)}$ Veterinary Surgery II, School of Veterinary Medicine and Animal Sciences, Kitasato University, 35-1 Higashi 23-bancho, Towada, Aomori 034-8628 and ${ }^{4}$ Institute for Biological Resources and Functions, National Institute of Advanced Industrial Science and Technology (AIST), 1-1-1 Higashi, Tsukuba, Ibaraki 305-8566, Japan

(Received 12 May 2005/Accepted 30 August 2005)

\begin{abstract}
Previous studies on human uterine and placental tissues have found variants, derived from alternatively spliced mRNAs, of preproendothelin-2 (PPET2) that lack a post-translational proteolytic site essential for normal processing. Here we report a splice variant of cat PPET2 mRNA expressed in the stomach. After cloning the full-length cDNA of cat PPET2, organ distribution analysis of the transcript by reverse transcriptase-polymerase chain reaction (RT-PCR) was performed. In addition to the fragment with a size predicted based on the cDNA sequence obtained by cloning, an additional PCR fragment of smaller size was detected in stomach tissue. Subsequent cloning and sequence analysis of the smaller PCR product demonstrated that it derives from a splice variant with full-length deletion of a region corresponding to exon 4 of the PPET2 gene.
\end{abstract}

KEY WORDS: cat stomach, feline preproendothelin-2, splice variant.

J. Vet. Med. Sci. 68(1): 55-58, 2006

Endothelin-2 (ET2), a member of the endothelin family of proteins, originally was identified as a human bioactive peptide with strong vasoconstrictive and pressor effects [4]. The bioactive mature ET2 peptide is generated from the precursor form, preproendothelin-2 (PPET2), through the activity of processing endopeptidases, including endothelin converting enzyme and dibasic amino acid endopeptidase, via a large intermediate propeptide known as big-ET2. Alternative human PPET2 splice variant mRNAs have been found in the course of mRNA expression analysis by reverse transcriptase-polymerase chain reaction (RT-PCR) [8]. Through conceptual analysis of the deduced amino acid sequences of the variant clones, it was demonstrated that some variant clones lack a nucleotide region that encodes a post-translational proteolytic processing site for dibasic endopeptidase, suggesting that, for these clones, the processing step leading to production of bioactive mature ET2 might be disrupted. Pursuant to this observation in human, the presence of splice variants of PPET2 has been explored in several animals including cow [14], horse [13], and dog [2]. However, apart from the human PPET2 mRNA variant, none has yet been found. In this manuscript, to examine whether the splicing that regulates the production of bioac- tive ET-2, as observed in human, may exist in cat organs, we cloned the full-length cat PPET2 cDNA and analyzed splice variants by RT-PCR in various organs.

To clone the full-length cat PPET2 cDNA, 5'- and 3'rapid amplification cDNA ends (RACE) was performed using a commercial RACE system (SMART ${ }^{\mathrm{TM}}$ RACE cDNA Amplification Kit, Clontech, U.S.A.), as previously described [12]. Briefly, after intestinal tissue from a healthy male cat, housed at Kitasato University under specificpathogen-free conditions, was homogenized with ISOGEN solution (Nippon Gene, Japan) to prepare total RNA. mRNA was purified from the total RNA with the QuickPrep $^{\mathrm{TM}}$ Micro mRNA Purification Kit (Amersham Biosciences Corp, U.S.A.). First-strand cDNA was synthesized from the mRNA using Moloney murine leukemia virus (MMLV) reverse transcriptase (Clontech, U.S.A.) according to the protocol provided by Clontech. Gene-specific (GSP) and nested gene-specific (NGSP) primers (Table 1), designed based on the consensus cDNA sequences of human PPET2 [7] and mouse prepro vasoactive intestinal contractor (PPVIC) [9], an orthologue of human PPET2, were used in 5'- and 3'-RACE polymerase chain reaction (PCR), together with oligonucleotides provided with the

Table 1. Primers used for cloning and cDNA amplification of cat PPET2 and GAPDH

\begin{tabular}{|c|c|c|c|}
\hline Name & Nucleotide sequence & & Used for \\
\hline 5'-GSP & 5'-AGGCC(A/G)TA(A/G)GGAGCTGTCTG-3' & (antisense) & cDNA cloning \\
\hline 3'-GSP & 5'-CCCGAGGCTCCCACCTGCGGACTCGACGTT-3' & (sense) & cDNA cloning \\
\hline 5'-NGSP & 5'-ACCCAGATAATGGCCA(A/G)GTG-3' & (antisense) & cDNA cloning \\
\hline 3'-NGSP & 5'-TTGCTCCTGCAGCTCCTGGCTCGACAAG-3' & (sense) & cDNA cloning \\
\hline PPET2/F & 5'-TGCAGCTCCTGGCTCGA-3' & (sense) & PCR \\
\hline $\mathrm{PPET} 2 / \mathrm{R}$ & 5'-AGTTCCCTCACTGCCACCTGTTGT-3' & (antisense) & PCR \\
\hline GAPDH/F & 5'-CTTCACCACCATGGAGAAGGC-3' & (sense) & PCR \\
\hline GAPDH/R & 5'-CTCATGACCACAGTCCATGCCA-3' & (antisense) & PCR \\
\hline
\end{tabular}


GAATGAGCTATCGGCTCTGCCTGGCAGC AAGACGCTGGCAACAGGCACGCTCCCTGCTCTGGTCCAGCCTGTGCGCTCCACCGCCACT ATGGTCGCCATGCCCACCGCCTGGTGCTCCATCGCCCTGGCCCTGCTCCTGGCCCTGCAT
$M$ V A M P T A W C S I A L A L L L A L H EXXON GAAGGCAAGGGCCAGGTGGCTGCTGCTCCGGACCAACCAGCACCCTCACACCGCGCCCGA

Fig. 1. Alignment of cat PPET2 nucleotide and deduced amino acid sequences. Apart from the poly (A) tail, the full-length cat PPET2 cDNA is 1248 bp. A 534-bp open reading frame encodes a 178-amino residue of cat PPET2 and is followed by the ATG codon closest to the 5' end, indicated by a shaded box. The stop codon is shown by an asterisk. The regions corresponding to endothelin mature, big and like peptides are indicated by a box, double-headed arrow and dashed box, respectively. Dibasic amino acid pairs, which are recognized by processing endopeptidase, are doubly underlined. The ATTTA consensus sequences associated with mRNA instability and the AATAAAA polyadenylation signal in the 3' non-coding region are indicated by underlines and dashed double underlines, respectively. Primer pairs designed to span exons 2, 3, 4 and 5 and used to search for splice variants are indicated by arrows. Putative exon organization predicted based on the gene structure of mouse PPVIC, which is the mouse orthologue of human PPET2, is also shown. Nucleotide and amino acid sequences are numbered to the right without and with parentheses, respectively. 


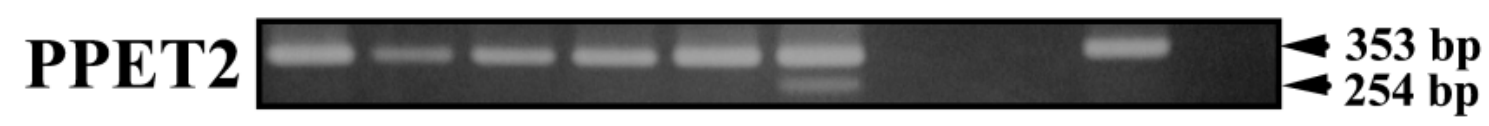

GAPDH $---\div-----\square$

\section{Te Bl Ki Co Do St Li Sp Lu He}

Fig. 2. Expression of cat PPET2 mRNA in various organs. PPET2 mRNA expression was examined in testis (Te), bladder (Bl), kidney (Ki), colon (Co), duodenum (Do), stomach (St), liver (Li), spleen (Sp), lung (Lu) and heart (He) by RT-PCR. GAPDH mRNA expression is shown as an internal control. Dominant 353-bp fragments are detected in testis, bladder, kidney, colon, duodenum, stomach and lung. In addition, a 254-bp PCR fragment, which derives from a splice variant mRNA, is found in stomach.

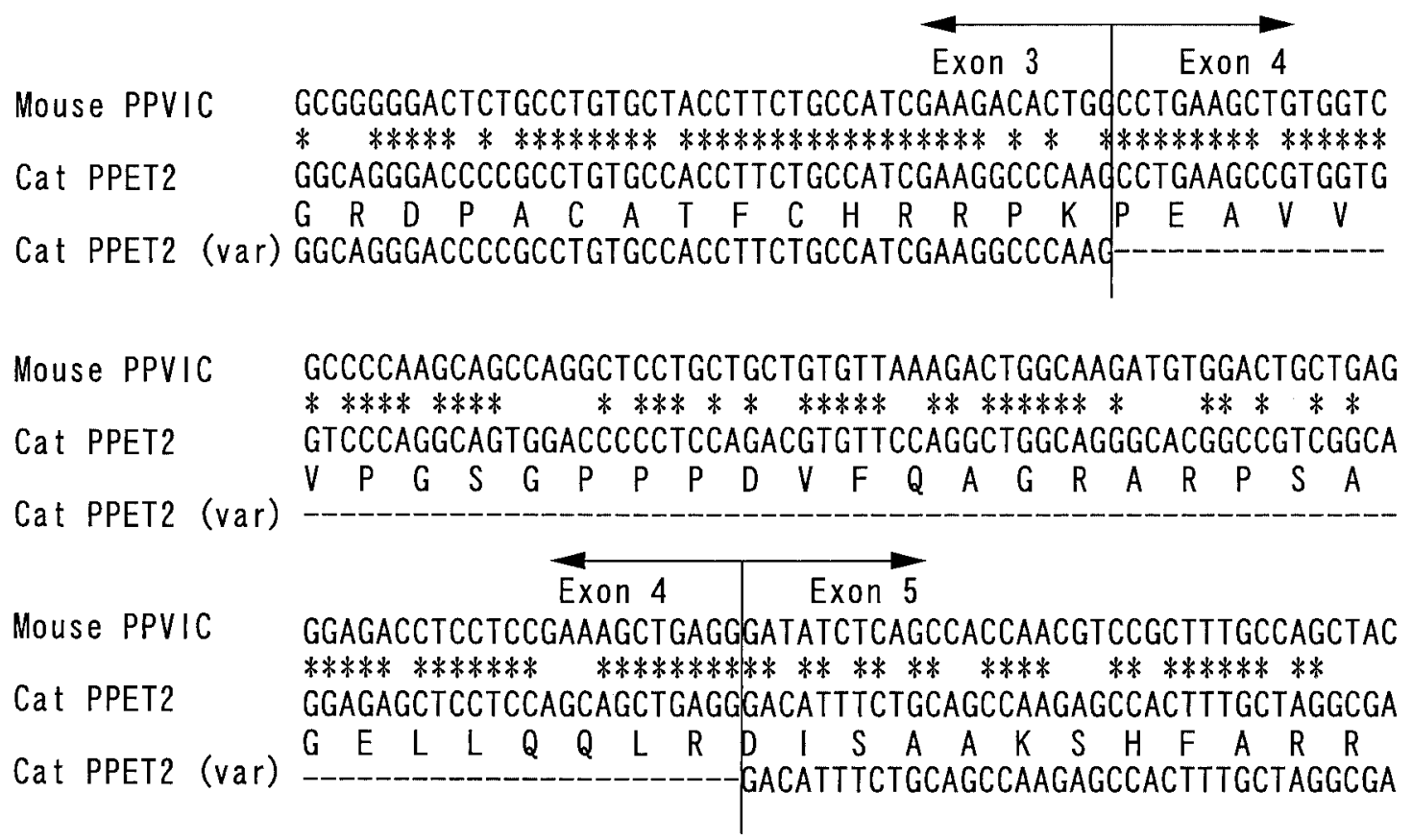

Fig. 3. Comparative alignment of intact cat PPET2 cDNA and splice variant clone sequences. Nucleotide and amino acid sequences of cat PPET2 along with those of the splice variant clone (var) from the 254-bp band in stomach (Fig. 2) are aligned, together with the mouse PPVIC cDNA sequence. Identical nucleotides are indicated by asterisks. Exon organization based on mouse PPVIC gene structure is also shown on the sequence. The variant completely lacks the nucleotide region corresponding to exon 4 .

RACE kit. The RACE PCR was performed under the following conditions: 5 cycles of $94^{\circ} \mathrm{C}$ for $5 \mathrm{sec}$ and $72^{\circ} \mathrm{C}$ for 3 $\min ; 5$ cycles of $94^{\circ} \mathrm{C}$ for $5 \mathrm{sec}, 70^{\circ} \mathrm{C}$ for $10 \mathrm{sec}$ and $72^{\circ} \mathrm{C}$ for $3 \mathrm{~min} ; 25$ cycles of $94^{\circ} \mathrm{C}$ for $5 \mathrm{sec}, 68^{\circ} \mathrm{C}$ for $10 \mathrm{sec}$ and $72^{\circ} \mathrm{C}$ for $3 \mathrm{~min}$; and 1 cycle of $72^{\circ} \mathrm{C}$ for $3 \mathrm{~min}$. After agarose gel electrophoresis of the PCR products, fragments of the expected size were purified and ligated into $\mathrm{pCR}^{\circledR} 2.1$ vector with a TOPO TA Cloning ${ }^{\circledR}$ Kit (Invitrogen, U.S.A.). Double-strand DNA sequencing was carried out by the Dye Terminator Sequencing method (BigDye ${ }^{\mathrm{TM}}$ Terminator Cycle Sequencing Ready Reaction Kit, Applied Biosystems, U.S.A.) using the ABI 310 DNA sequencer. The fulllength cat PPET2 cDNA sequence was obtained by combining sequences from the 5'- and 3'-RACE PCR. Figure 1 shows the resultant full-length nucleotide sequence of cat PPET2 cDNA, along with the deduced amino acid sequence. The cDNA, which comprises 1248 bp apart from the poly (A) tail, includes an open reading frame of $534 \mathrm{bp}$ encoding a 178-amino acid polypeptide. On the deduced polypeptide the regions corresponding to a mature ET2 $\left(\mathrm{C}^{49}-\mathrm{W}^{69}\right)$, an intermediate form known as big-ET2 $\left(\mathrm{C}^{49}\right.$ $\left.\mathrm{P}^{86}\right)$ and ET2-like peptide $\left(\mathrm{C}^{96}-\mathrm{H}^{111}\right)$ are observed. Paired dibasic amino residues, which are recognized for post-translational processing by dibasic endopeptidases, directly flank both the $\mathrm{N}$ - and C-terminals of the big-ET2 and the like-peptides, suggesting that the two peptides are cut from the precursor protein by proteolytic processing. The presence of a target site $\left(\mathrm{W}^{69}-\mathrm{V}^{70}\right)$ for endothelin converting enzyme 
within the big-form suggests that the bioactive mature ET2 peptide is generated through cleavage at that position. In the 3 '-untranslated region of the cDNA, two copies of the consensus sequence, ATTTA, which is related to mRNA destabilization, are found at positions 1162-1166 and 11941198 , as was shown for the mouse PPVIC gene [10] and cytokine genes $[1,3,5]$.

To assess the organ distribution of cat PPET2 mRNA, as well as that of any potential splice variant, specific primers (PPET2/F and PPET2/R) were designed to span exons 2, 3, 4 and 5 to generate a 353-bp fragment based on the fulllength cDNA sequence obtained by cloning (Table 1 and Fig. 1). Primers for the glyceraldehyde-3-phosphate dehydrogenase gene (GAPDH/F and GAPDH/R) were designed so that the mRNA could be used as an internal control (Table 1). With total RNA extracted from testis, bladder, kidney, colon, duodenum, stomach, liver, spleen, lung and heart of a healthy cat, first-strand cDNAs were synthesized using the RNA PCR Kit (TaKaRa, Japan). PCR was performed with AmpliTaq Gold DNA polymerase (Applied Biosystems, USA) under the following conditions: 1 cycle of $95^{\circ} \mathrm{C}$ for $10 \mathrm{~min} ; 35$ (PPET2) or 25 (GAPDH) cycles of $95^{\circ} \mathrm{C}$ for $1 \mathrm{~min}, 65^{\circ} \mathrm{C}$ for $1 \mathrm{~min}$ and $72^{\circ} \mathrm{C}$ for $1 \mathrm{~min}$; and 1 cycle of $72^{\circ} \mathrm{C}$ for $30 \mathrm{sec}$. Figure 2 is the electrophoresis showing the organ distribution of cat PPET2 mRNA expression. A 353-bp fragment predicted from the cloned cDNA sequence was detected in testis, bladder, kidney, colon, duodenum, stomach and lung. The finding of predominant PPET2 mRNA expression in cat gastrointestinal tract is in concordance with the results of previous studies in mouse [15], rat [11], cow [14], horse [13] and dog [2]. In addition to the PCR fragment with the predicted size, another smaller, less abundant product was found in the stomach, but not in any of the other organs examined. To determine whether the amplified fragment was a splice variant of cat PPET2 mRNA, we cloned and sequenced the PCR fragment. Figure 3 shows the partial alignment of cat PPET2 cDNA sequence from the 353-bp product with the sequence of the 254-bp fragment from the stomach. A putative exon organization, predicted based on mouse PPVIC gene structure [10], is also shown. This comparison demonstrates that the 254-bp clone is a splice variant with complete deletion of a 99-bp region corresponding to exon 4 of the PPET2 gene. Even though the variant mRNA is spliced in the region encoding the carboxy-terminal portion of PPET2, none of the functional regions are comprised by splicing because both the mature ET2 peptide and putative target sites for processing endopeptidases reside in the remaining amino-terminal portion. Thus the splicing has no effect on the production of bioactive ET2 peptide or on the processing steps. In human placental and uterus tissues, seven alternatively spliced mRNA variants have been reported [8]. Among the variants there exist two clones lacking a processing target site (R-R) flanking the carboxy-terminal portion of big-ET2, suggesting disruption of the post-translational processing that produces big-ET2, a precursor for mature ET2. Because the PPET2 splicing variant observed in healthy cat stomach tissue produces no disruption of ET2 peptide synthesis, the functional effects of splicing on this gene may be of little physiological significance. However, given the fact that ET2 is implicated in the pathophysiology of gastric mucosal injury, with marked elevation of mRNA expression in situ [6], the question of whether any splicing that affects the regulation of bioactive ET2 production might occur in the injured cat stomach is still of interest. Further study to determine the mechanism for the regulation of ET2 synthesis via a splicing pathway is necessary.

Sequence data in this article have been deposited with the EMBL/GenBank/DDBJ Data Libraries under Accession No. AB197699

ACKNOWLEDGEMENTS. This work was supported by a Grant for Scientific Research (No.S0501) from the School of Veterinary Medicine and Animal Sciences, Kitasato University and by a Grant-in-Aid for Scientific Research (No. 17580271) from the Japan Society for the Promotion of Science (JSPS).

\section{REFERENCES}

1. Chesney, J., Mitchell, R., Benigni, F., Bacher, M., Spiegel, L., Al-Abed, Y., Han, J.H., Metz, C. and Bucala, R. 1999. Proc. Natl. Acad. Sci. U.S.A. 96: 3047-3052

2. Fujimori, Y., Uchide, T., Saida, K., Temma, K., Sasaki, T. and Akera, T. 2003. J. Vet. Med. Sci. 65: 1217-1225.

3. Gueydan, C., Droogmans, L., Chalon, P., Huez, G., Caput, D. and Kruys, V. 1999. J. Biol. Chem. 274: 2322-2326

4. Inoue, A., Yanagisawa, M., Kimura, S., Kasuya, Y., Miyauchi, T., Goto, K. and Masaki, T. 1989. Proc. Natl. Acad. Sci. U.S.A. 86: $2863-2867$.

5. Jarrousse, A.S., Petit, F., Kreutzer-Schmid, C., Gaedigk, R. and Schmid, H.P. 1999. J. Biol. Chem. 274: 5925-5930.

6. Kozakai, T., Zhao, H., Sakate, M., Masuo, Y., Uchide, T. and Saida, K. 2002. Clin. Sci. 103: 455S-458.

7. Ohkubo, S., Ogi, K., Hosoya, M., Matsumoto, H., Suzuki, N., Kimura, C., Ondo, H. and Fujino, M. 1990. FEBS Lett. 274: $136-140$.

8. O'Reilly, G., Charnock-Jones, D.S., Morrison, J.J., Cameron, I.T., Davenport, A.P. and Smith, S.K. 1993. Biochem. Biophys. Res. Commun. 193: 834-840.

9. Saida, K. and Mitsui, Y. 1991. Biochim. Biophys. Acta. 1089: 404-406.

10. Saida, K., Hashimoto, M., Mitsui, Y., Ishida, N. and Uchide, T. 2000. Genomics 64: 51-61.

11. Uchide, T., Adur, J., Fukamachi, T. and Saida, K. 2000. J. Cardiovasc. Pharmacol. 36: S5-8.

12. Uchide, T., Fujimori, Y., Sasaki, T., Temma, K., Lee, Y.S. and Saida, K. 2002. DNA Seq. 13: 369-374.

13. Uchide, T., Fujimori, Y., Temma, K., Sasaki, T. and Saida, K. 2004. J. Cardiovasc. Pharmacol. 44: S430-434.

14. Uchide, T., Fujimori, Y., Temma, K., Sasaki, T. and Saida, K. 2003. DNA Seq. 14: 385-392.

15. Uchide, T., Masuda, H., Mitsui, Y. and Saida, K. 1999. J. Mol. Endocrinol. 22: 161-171. 